\title{
Buy, Hold or Sell? A Study on Islamic Institutional Investors' Investment Decision Behavior in Bursa Malaysia
}

\author{
Rabuan Mantine ${ }^{* a}$ and Mohamad Jais ${ }^{b}$ \\ ${ }^{a}$ School of Business and Management, University College of Technology Sarawak, \\ Sibu, Sarawak, Malaysia \\ ${ }^{b}$ Faculty of Economics and Business, Universiti Malaysia Sarawak \\ *Corresponding Author: rabuanm1@gmail.com
}

\begin{abstract}
The global search for shariah-compliant investment as alternatives to Western style markets spurred by the turmoil in Asian financial markets in 1997. This has brought the new Islamic screens or Indices into being in most parts of the world along with Islamic fund managers which are mushrooming to cater for the ever increasing needs of the new type of investors who are governed by Islamic ethics. In the Islamic perspective, speculations are prohibited while short-selling and margin trading are severely restricted, something unheard of in conventional western market. Based on that notion, it would be interesting to know whether the Islamic investors who participate alongside other investors in the stock markets, behave differently in their investment decisions. Hence, this study, investigates on whether Islamic investors in the Bursa Malaysia place shariah-compliant status of a firm as main criteria of their investment decisions. The results showed clear indication that Islamic institutional investors still favor shariahcompliant firms over shariah non-compliant firms, meaning that firms losing shariahcompliant status would lose Islamic investors as well. An implication for firms and fund managers is that, understanding the Islamic investors' investment decisions is important should they consider attracting Islamic investors in their firms or funds.
\end{abstract}

Keywords: Wealth, SRI Investors, Islamic investors, Shariah-compliant Index, Islamic investment, Investors' behaviour

\section{Introduction}

Little research has been carried out in the area of Islamic investors. Although some researchers have paid attention to Islamic perspective on instruments traded and the structure and practices of stock markets (Naughton \& Naughton, 2000, Forte \& Miglietta, 2007) and the performance of shariah-compliant indices and shariahcompliant funds (Hakim \& Rashidian, 2002; Rahman \& Wajdi, 2006; Girard \& Hassan, 2006; Sadeghi, 2008; Rahim et al., 2009; Rahim \& Yong, 2010), little is known about how Islamic investors behave or make decisions when trading in the stock market.

Furthermore, the search for alternatives to Western style markets has only began since the turmoil in Asian financial markets in 1997 (Naughton \& Naughton, 2000). So far the literature on shariah-compliant investment such as the performance of the new 
Islamic indices and Islamic funds have not distinguished Islamic investors with others, let alone studying their investment decision behaviour in the stock market.

In principle, Islamic investors are subscribed to Islamic values in their investment decisions. In this regard, it is important to note that, in the Islamic perspective, speculation is not acceptable while short selling and margin trading are severely restricted (Naughton \& Naughton, 2000). Thus, a motivation for the Islamic investors is different from ethical investors, speculators or any other investors for that matter. To appreciate the motive and behavior of Islamic investors in the stock markets, it would be worthwhile to draw parallel from the illustration below on the strict observation required on Muslim while performing the fifth (final) pillar of Islam i.e. Hajj or pilgrimage to Mecca.

"And Hajj (pilgrimage to Makkah) to the House (Ka'bah) is a duty that mankind owes to Allah, those who can afford the expenses (for one's conveyance, provision and residence).."

[The Qur'an 3:97]

As explained by Yakub Mirza of Amanafunds, a Muslim has to be economically able to make the trip. If he has to borrow the money to make the journey, Hajj is not compulsory on him. In order to make the Hajj, a pious Muslims must first pay off their debts, including the zakat due on their wealth; to return whatever was given them in trust; and have enough savings to bear the expenses of the journey (such as travel, Hajj tax, and lodging) and the sacrifice (of an animal). Besides this, they also have to provide for their families and dependents during their absence (Mirza, 2013).

Analogies drawn from the above give us a glimpse on the fastidiousness of Islamic investors in selecting stocks while investing in stock market. Because of these unique characteristics the Islamic investors are different from ethical investors who are motived by their common ethics and also off course speculators who are unrestrained by any ethic in their investment decisions.

The emphasis on the avoidance of forbidden transactions such as speculation, and the restriction on short-selling and margin trading in the Islamic perspective as discussed above therefore, led us to believe that Islamic investors would be first and foremost attracted to shariah-compliant status of a firm, above anything else. However, such perception has got to be verified considering other factors or concerns that might also influence their investment decisions. Focusing on the Islamic institutional investors in Bursa Malaysia covering the period of 1999 to 2010, this study would, therefore, seeks to address question on the behavior of the Islamic investors with regard to their investment decisions. Based on the assumption that Islamic investors are "values-driven" the hypothesis is developed as per below;

\section{Hypothesis: The Islamic Institutional Investors Are Drawn To The Firms' Shariah- Compliant Status Over Firms' Performance.}

The remainder of the article is structured as follows: First, the literature review, then followed by sample data and method of research procedures used in the study. Third, the empirical results and finally, the conclusion that concludes on the implications as well as limitations of the study and also recommend future directions for future research. 


\section{Literature Review}

\section{Wealth and the Philosophy of Islamic Investment}

In Adam Smith's work (Smith, 1776), wealth is discussed in the context of a single nation which encompasses both private and public assets and goods at the beginning of industrial revolution. While, the creation of wealth is, on the other hand, defined by Enderle (2000) as the production of public and private assets which involves the market and price mechanism. Thus, in the context of private assets such as investment in a firm, wealth is primarily the stocks.

From the above definitions, there already is a distinction between wealth creation in a nation as well as in a firm. For a nation, wealth creation is often inseparable to the noble objective of poverty eradication. While for firms, management literature mostly consider "maximizing shareholder's value" as the firm's objective thus negates the economic responsibilities of business organizations.

It is against the above backdrop emerged the term called Corporate Social Responsibility (CSR) movement which expects a firm to behave like a good corporate citizen to share its wealth with communities. CSR has now become a subject of study by financial economists (Lougee \& Wallace, 2008). CSR movement also has given rise to the Socially Responsible Investment (SRI) movement which select investment portfolio based on firms' corporate social responsibility involvements (Fung, Lau, \&Yau, 2010).

\section{What Are The Underlying Principles Of Islamic Investors?}

While SRI or ethical investment is the action of investors who by choice invest in socially responsible firms or funds, Islamic investment, in the same breath, is the action of Islamic investors who invest in accordance with the shariah-compliant investments. Having said that, however, the motivation for SRI investors might not be the same as the motivation for Islamic investors.

First of all let's look at the concept of wealth in Islam and how it is related to investment. According to Mansor (2006) all wealth is the possession of Allah with which humans are entrusted. This is in reference to the verse in the Holy Quran that emphasizes the need to pursue one's share of wealth in this world which is clearly stated as a reminder.

"But seek, with the (wealth) which Allah has bestowed on thee, the Home of the Hereafter, nor forget thy portion in this world: but do thou good, as Allah has been good to thee, and seek not (occasions for) mischief in the land: for Allah loves not those who do mischief."

(Surah Al-Qasas, 28:77)

Thus, seeking wealth is a responsibility. It must be earned through permissible means and spent in permissible ways, such as spending on one's self and those for whom he is responsible for, without extravagance or waste. Wealth should be actively invested and should not be kept idle. Needless to say, the means of investment should also be allowed under Islamic law. It is also a duty under Islamic economic principle that wealth to be circulated so that it would not be confined amongst the rich. The most important mechanism for distribution of wealth in Islam is in the form of zakah where wealth generated are purified through zakah contribution which in turn distributed to the zakah 
beneficiaries such as the poor thus elevating the economic well-being of the Muslims (Shafi, 1968; Al-Qaradawi, 1999).

In Islam, providentially, the virtues of investment philosophy are in fact, embedded in the very prohibitions under the shariah law i.e., the prohibition of usury (riba), gambling or speculation (maisir) and ambiguity (gharar) (Naughton \& Naughton, 2000).

Accordingly, based on the shariah principle, transactions taking place in the capital market should be free from activities with those prohibited elements. Wealth creation through shariah-compliant firms, therefore, be defined as investment in financial services and other investment products, which adhere to the principles established by the shariah. According to Naughton and Naughton (2000) these principles require that:

i. Investment must be made in ethical sectors. In other words, profits cannot be generated from prohibited activities such as alcohol production, gambling, pornography etc. In addition, investing in interest riba-based financial institutions are not allowed.

ii. All wealth creation should result from a partnership between an investor and the user of capital in which rewards and risks are shared. Returns in invested capital should be earned rather than be pre-determined. For that reason, in the case of equity investment in the stock market only common stock qualifies as shariahcompliant investment alternative by virtue of its profit (or loss) sharing attribute while preference stock does not qualify for its interest bearing feature.

As stocks and financial markets were all started in western countries, the conversion to Islamic investment products that comply with shariah requirements have to be structured for the purpose of Islamic investment. This is made possible through financial engineering i.e. the process of ijtihat within the context of Islamic jurisprudence. However, it is worth mentioning here that not every transaction in the Islamic finance have to be established through the process of ijtihat. While defining the halal and haram constitute the shariah aspect, how and when to buy and sell (a stock) is solely based on reasons and facts. Likewise, man does not have to resort to the Quran and sunnah to make economic forecast and or execute stock purchases (Rosly, 2005, p. 28).

\section{What Is The SRI Investors' Behaviour In Investment Decisions?}

Previous researchers (Heinkel, Kraus, \& Zechner, 2001, Statman, Fisher, \& Anginer 2008; Hong \& Kacperczyk, 2009) defined SRI investors as "values-driven" investors based on assumptions that SRI investors integrate corporate social responsibility (CSR) criteria into investment decisions instead of financial considerations. This view implies this type of investors accept a loss of financial performance in exchange for non-financial utility derived from the SRI attribute of their investment. The other type of investors are defined as "wealth-maximizing" investors who traditionally pursue pecuniary utility over values. While the results of earlier studies (e.g., Heinkel et al., 2001; Fama \& French, 2007; Statman et al., 2008; Hong \& Kacperczyk, 2009) have shown investors who pursue non-financial goals affect asset prices and returns differently compared to the traditional wealth-maximizing investors.

Likewise, similar studies also performed on Islamic indices or screen and Islamic funds which result in the "outperformance theory" and "underperformance theory". Arguments for "outperformance theory" suggest that responsible non-financial investment criteria inherent in the shariah law represents advanced risk management. 
Shariah compliance in Islamic investing also encourages firms to adopt corporate responsibility policy to put them in a better position to avoid any environmental and social crises that could lead to reputation damage, higher production costs, lost production, higher security costs and increased insurance premium (Hakim \& Rashidian, 2004, Hussein, 2005; Lee \& Faff, 2009). 'Underperformance theory' (Campbell \& Vuolteenaho, 2004; Geczy, Stambaugh, \& Levin, 2005; Hong \& Kacperczyk, 2009) on the other hand, holds that Islamic investing such as Islamic funds underperform conventional counterparts as a higher screening intensity reduces the performance of Islamic funds. The shariah-index screening unnecessarily limits one's potential universe of investments, thus dampening the benefits achieved by diversification. Shariahcompliant screening also results in the exclusion of some standard 'sin' stocks (alcohol, gambling, and tobacco) that deliver significantly positive abnormal returns and were among the world best performers even during recent global recession. Besides, lower debt ratio criteria set-out in the shariah-compliant screening exposes Islamic investment to growth stocks than value stocks, as the former are considered to have a lower leverage than the latter different from the prevalent, mainstream social environment will face negative consequences as a result of their observance.

Unfortunately, all the studies above are on the performance of the indices, funds or stocks that adhere to the CSR requirements. While attempts were made to study the investment decision behaviour of SRI investors, it was based on the assumption that the movement of the stock prices or performance were the results of the SRI investors' investment decisions alone. There is flaw in this method. The fact is that, SRI investors are not the controlled groups that can be easily identified. In that sense, it is possible that a person becomes SRI investor in one investment decision and compromised his belief in another. Thus, previous studies on SRI are merely on the ability of the SRI screen or indices to win new SRI movement's "convert" rather than studying the investment decision behaviour of an identified group of SRI investors towards SRI screen or indices. Accordingly, these methods failed to examine different behaviour of the same SRI investors in their investment decisions given different market conditions or circumstances.

To fill this gap, this study therefore identified the institutional Islamic investors and tract their investment decisions behaviour in the stock market.

\section{Methodology}

\section{Data of Selected Islamic Investors and Firms}

Data for Islamic investors is proxied by the recognized shariah-compliant institutional funds as issued by Securities Commission Malaysia and published in its website. Similarly, the data for shariah-compliant firms are based on the list of shariahcompliant securities published by Securities Commission Malaysia.

The samples are collected from 1999 to 2010 periods. For the purpose of studying the behavior of Islamic investors on shariah-compliant firms, only firms with shariah-compliant status' changes are selected. Changes in shariah-compliant status mean a firm either attaining shariah compliant status or losing shariah-compliant status. Firms attaining shariah-compliant status would be included in the Kuala Lumpur Shariah Index (KLSI) (grouped into Sample-A) and in the contrary firms losing shariahcompliant status would be excluded from KLSI (grouped into Sample-B). The grouping of the samples and the number of firms in the samples are shown in the Figure 1 and Figure 2 respectively as per below: 


\begin{tabular}{|c|c|c|}
\hline Sample Grouping & Shariah compliance Status Changes & Remark \\
\hline Sample A & $\begin{array}{c}\text { Attaining shariah-compliant status and } \\
\text { Included in KLSI }\end{array}$ & New Firms \\
\hline Sample B & $\begin{array}{c}\text { Losing shariah-compliant status and } \\
\text { Excluded from KLSI }\end{array}$ & Mature Firms \\
\hline
\end{tabular}

\section{Figure 1: Sample A and Sample B}

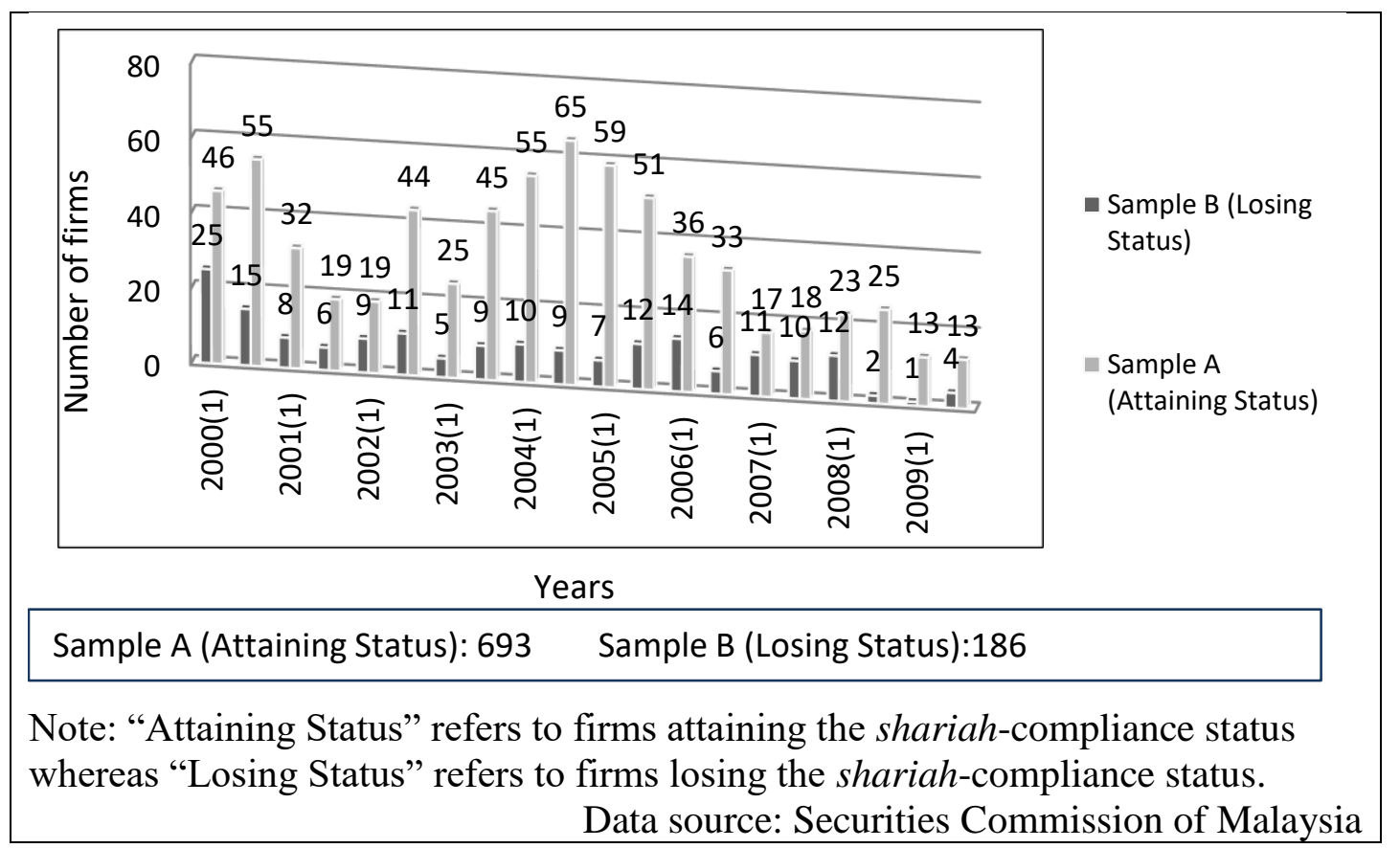

Figure 2: Firms attaining and losing shariah-compliance status in Kuala Lumpur Shariah Index (KLSI) for the periods 2000-2009

\section{Data Items of the Selected Firms}

For each change in shariah-compliant status in the sample, the accounting data for the minimum of one year $(-1$ to +1$)$ surrounding the status announcement year are obtained. Year 0 , or the base year, is defined to be the fiscal year corresponding to the calendar year of the shariah-compliant status announcement. For instance, if a shariahcompliant status announcement took place in calendar year 2000, then the base year for the Data Stream database will be fiscal year 1999 regardless of when in the year 2000 the shariah-compliant status announcement took place. The announcements of the changes in shariah-compliant status of a firm in Bursa Malaysia are made twice a year which are usually in May and November.

In some analysis where the impacts of different market conditions are required the data are further divided into two periods namely Period P1 (year 2000 to 2004) to represent market recovery period and Period P2 (year 2005 to 2009) for market stability period as in the Kuala Lumpur Composite Index (KLCI).

\section{Analytical Technique}


In the hypothesis, the Islamic institutional investors are expected to be drawn to the firms' shariah-compliant status over firms' performance. There are two methods to test the hypothesis namely, the Paired $t$-test and Ordinary Least Square (OLS) methods. The Islamic institutional investors are based on the list of Institutional Funds issued by Securities Exchange of Malaysia which are accorded 'Islamic Fund' status after fulfilling specific criteria under Shariah law as well as Lembaga Tabung Haji which is among the earliest and probably the biggest Islamic fund in Malaysia.

\section{Paired $t$-test}

The changes in size of Islamic institutional investors ownership (in percentage) is analyzed by employing paired $t$-test on means of the pre ( -3 to -1 years) and post $(+1$ to +3 ) event year of both new firms and mature firms represented by sample $A$ and sample $\mathrm{B}$ respectively. Based on the hypothesis, the Islamic institutional investors are expected to show greater presence during shariah-compliant period.

\section{OLS Methods}

The impact of shariah-compliant status changes and other firms' performances on Islamic Investors institutional ownership is analyzed using the Ordinary Least Squire (OLS) model.

Similar OLS model was used by Bichara (2008) who investigated the relationship between institutional ownership characteristics specifically on tax effect (Tax law changes) and the dividends.

In this study however, the OLS model is used to analyze the impact of shariahcompliant status changes on Islamic institutional investors ownership, as stated in this hypothesis, where the changes in Islamic investors institutional ownership are observed between pre- $(-1)$ and post- $(+1)$ event year. Specifically, the hypothesis postulates that the shariah-compliant status would attract the Islamic institutional investors as compared to other firm's performances as proxied by market capitalization, debt-to-asset ratio, book-to-market ratio, free cash flow and return to asset. The firm performance variables are selected to represent important aspects such as size, leverage, investment opportunity, growth, and profitability of a firm.

\section{The variables}

The dependent variable in this OLS method is the size of Islamic institutional investors common share ownership (in percentage) whereas the independent variables, besides the shariah-compliant status are the other aspects of firm' performance.

The methods used for these firm performance variables are similar to previous studies. For examples, the market capitalization is used to measure the firms' characteristic in term of size of the company, while company's debt-to-asset ratio is used to measure leverage. For investment opportunity, on the other hand, the book-to-market ratio is used. While, growth prospect of a firm is also considered as proxied by free cash flow in the firm's characteristics. The profitability of a firm is represented by return on asset ratio. The justifications and explanations on the methods used on these variables are as below; 


\section{Market Capitalization}

Market capitalization represents the aggregate value of a company or company's size. Generally, most stock market recognizes three market cap divisions: large cap, mid cap, and small cap, although the cutoffs between the categories are not precise or fixed. This measure is consistent with Baker and Hall (2004), Del Guerico (1996), Gompers et al. (2001), and Bichara (2008). This measure is calculated using calendar year price times common shares outstanding. The equation for market capitalization is illustrated as below:

Market Capitalization $=$ Market Price $\mathrm{x}$ Number of Shares Outstanding

\section{Debt-to-Assets ratio}

The measure of debt is long-term debt and likewise asset is represented by longterm asset. The debt-to-asset ratio is the measure of a company's financial leverage, which is consistent with the paper by Wald (1999). Debt-to-assets ratio is equal to longterm debt divided by long-term asset. It is important to realize that if the ratio is greater than one (1.0), the majority of assets are financed through debt. If it is smaller than one (1.0), assets are primarily financed through equity. Investing in a company with a higher debt-to-asset ratio may be riskier, especially in times of rising interest rates, due to the additional interest that has to be paid out for the debt. The equation for debt-to-asset ratio is represented below:

\section{Total Debt to Total Assets $=($ Total Debt $) /($ Total Assets $)$}

\section{Book-to-market ratio}

Book-to-market ratio is used to measure a company's investment opportunities, which is consistent with past literature (Grullon \& Michaely, 2004; Fenn \& Liang; 2001; Smith \& Watts, 1992). Low book-to-market ratio also represents one characteristic of stocks with high S\&P rankings for which institutional investors' exhibit high preference (Del Guerico, 1996). Book-to-market ratio is calculated as book value per share divided by market price per share, where the book value per share is common equity divided by shares outstanding taken from the company's balance sheet as per equation below:

$$
\text { Book to Market }=(\text { Book Value of Firm }) /(\text { Market Value of Firm })
$$

A ratio above one (1.0) indicates a potentially undervalued stock, while a ratio below one (1.0) indicates a potentially overvalued stock. Technology companies and other companies in industries which do not have a lot of physical assets tend to have low book to market ratios.

\section{Free Cash flow}

Free cash flow represents the cash that a company is able to generate after laying out the money required to maintain or expand its asset base. It is also a measure of financial performance and is important because it allows a company to pursue opportunities that enhance shareholder value. Without cash, it's tough to develop new products, make acquisitions, pay dividends and reduce debt.

Free cash flow is commonly used in much of the corporate finance literature as a proxy for firms that have excess cash after funding all positive net present value projects (Jensen, 1986; Fenn \& Liang, 2001). In other words, it is essentially the money 
that the company could return to shareholders if the company was to grow no further. Free cash flow is calculated as operating cash flows (net income plus amortization and depreciation) minus capital expenditures and dividends similar to Fenn and Liang (2001). When positive, it shows what can be paid out to equity holders (as a dividend or repurchased stock) without damaging the firm's operations or growth opportunities. When negative, it implies that the firm must issue new equity or raise debts in order to increase cash. Negative free cash flow is not necessarily an indication of a bad company, however, since many young companies put a lot of their cash into investments, which diminishes their free cash flow. But if a company is spending so much cash, it should have a good reason for doing so and it should be earning a sufficiently high rate of return on its investments. Free cash flow is calculated as:

Free Cash Flow $=$ Operating Cash flow - Capital Expenditure - Dividend

\section{Return on Assets}

Return on assets is an indicator of how profitable a company is before leverage, and is compared with companies in the same industry. Since the figure for total assets of the company depends on the carrying value of the assets, some caution is required for companies whose carrying value may not correspond to the actual market value. Return on assets (ROA) is a common figure used for comparing performance of financial institutions (such as banks), because the majority of their assets will have a carrying value that is close to their actual market value. Return on assets is not useful for comparisons between industries because of factors of scale and peculiar capital requirements (such as reserve requirements in the insurance and banking industries).

Following Barber and Lyon (1997) return on assets is calculated by dividing a company's annual earnings or net income by its total assets (TA) and displayed as a percentage by equation below:

$$
\mathrm{ROA}=(\text { Net Income }) /(\text { Total Assets })
$$

\section{The OLS Model}

The OLS model is represented as below;

$$
\begin{aligned}
& \text { IslamicInvestor }=\alpha+\beta_{1} \text { ShariahComp }+\beta 2 \text { LMktCap }+\beta_{3} \text { DebtAsset } \\
& +\beta_{4} \text { BTM }+\beta_{5} \text { FCFlow }+\beta_{6} \text { ROA }+\varepsilon i
\end{aligned}
$$

And the Islamic institutional investor is defined as the percentage of common equity ownership in the firms as below;

$$
\text { IslamicInvestor }_{t}=\frac{\text { Common Shares Owned }}{\text { Total Common Equity }}
$$

Where;

(i) Independent variables in (1); 


$$
\begin{aligned}
& \alpha=\text { the intercept (the value of dependent variables when the value } \\
& \text { of all independent variables are zero); } \\
& \beta_{1} \text { to } \beta_{6}=\text { are the vectors or slopes associated with the independent } \\
& \text { variables (also called regression coefficients); }
\end{aligned}
$$

(ii) Dependent variable in (2);

Common Shares Owned $_{t}=$ common shares owned by Islamic investors at the date $t$

Total Common Equity $=$ total common equity at the date $t$; and

$t$

$=$ the date corresponding to the accounting year end in the company's balance sheet.

\section{Empirical Results}

\section{The results of the Paired $t$-test and OLS regression analysis}

Although the results OLS regression (see Table 2) do not appear to support the correlation part of the hypothesis, the indication is clear that Islamic institutional investors still favor shariah-compliant firms over shariah non-compliant firms, as proven by the results of the Paired $t$-test (see Table 1) which demonstrate Islamic institutional investors' equity ownership significant surge in firms attaining shariahcompliant status (Sample A) in all market conditions registering positive differences in means of 0.4121 (Overall Period), 0.4243 (Recovery Period) and 0.3970 (Stability Period) respectively at $1 \%$ significant level.

There is no evidence to suggest that there is significant difference between Islamic institutional investors' ownership during shariah-compliant financial years and shariah non-compliant financial years in sample B for both periods (see Table 1). Apparently, the results show the Islamic institutional investors' preference of shariah- 
compliant firms over shariah non-compliant firms in sample A. As for the test results on sample B, one possible explanation is that, the majority of the Islamic institutional investors may have fled the firms earlier in anticipation to the imminent annulment of the firms' shariah-compliant status. This is corroborated by the sample statistics (see Table 3) that showed the depleting Islamic institutional investors ownership in sample $\mathrm{B}$ with means ranging from 0.05 to 0.42 as compared to sample A with means ranging from 0.89 to 1.66 .

Further, the results of the OLS regression analysis (see Table 2) on Sample A, go to show that the Islamic institutional investors' investment decisions are not influenced by the firms' other variables either perhaps added by the fact that relatively new firms (in Sample A) with freshly issued shariah-compliant status are perceived as homogenous in characteristics largely after undergoing the stringent shariah screening process. 
Table 1: Paired $t$-test for Islamic Institutional Investors' equity Ownership for Sample A and Sample B

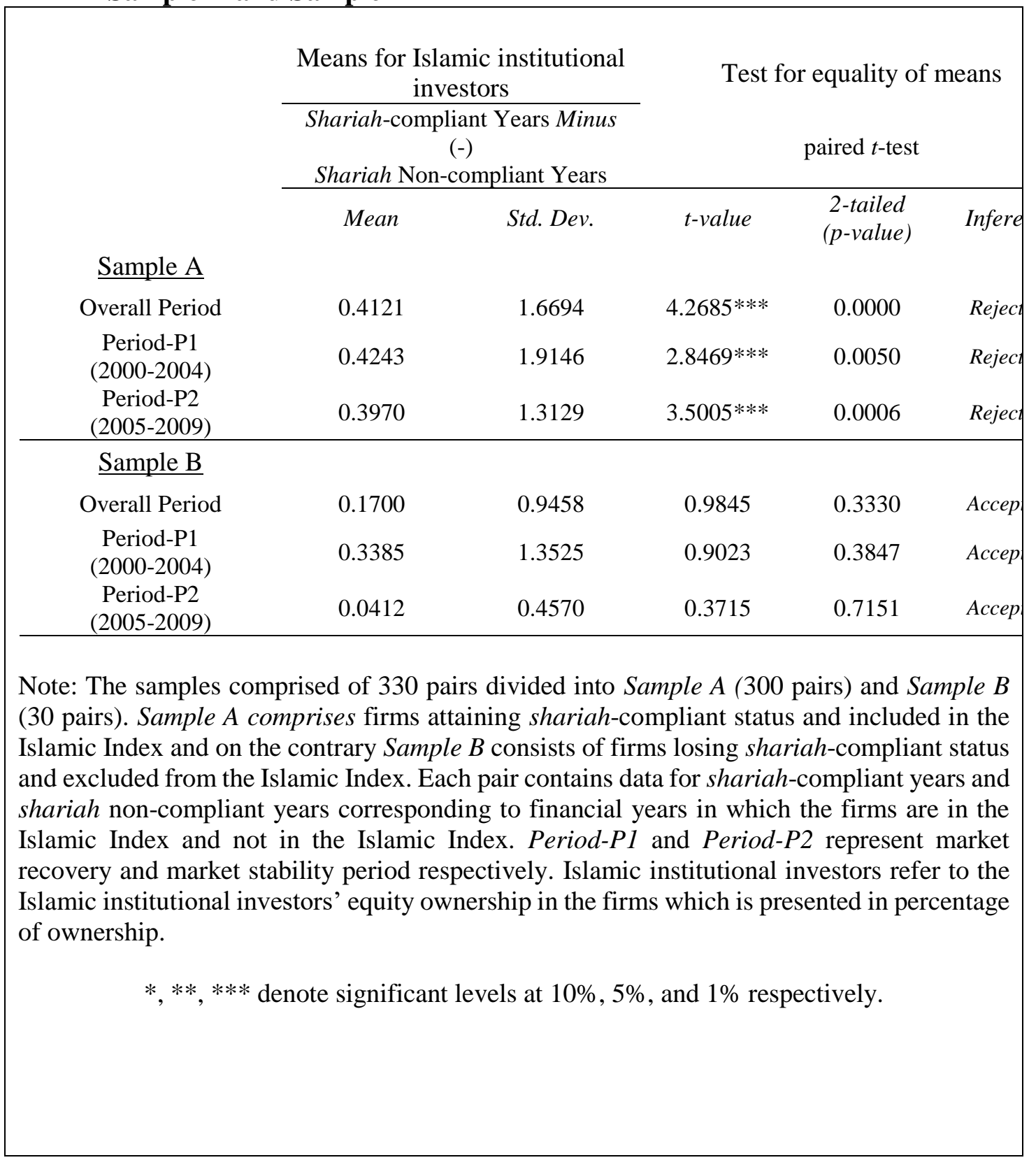

Table 2: OLS Regression Analysis on the Correlation of the Islamic Institutional Investors (IslamInvestor) to Shariah-compliant Status (ShariahComp) in Sample A and Sample B 


\begin{tabular}{|c|c|c|c|c|c|c|}
\hline \multirow{4}{*}{ Variables } & \multicolumn{6}{|c|}{ Dependent Variable: Islamic institutional Investor (IslamicInvestor) } \\
\hline & \multicolumn{3}{|c|}{$\underline{\text { Sample A }}$} & \multicolumn{3}{|c|}{$\underline{\text { Sample B }}$} \\
\hline & $\begin{array}{l}\text { Overall } \\
\text { Period }\end{array}$ & $\begin{array}{c}\text { Period-P1 } \\
(2000-2004)\end{array}$ & $\begin{array}{c}\text { Period-P2 } \\
(2005-2009)\end{array}$ & $\begin{array}{c}\text { Overall } \\
\text { Period }\end{array}$ & $\begin{array}{c}\text { Period-P1 } \\
(2000-2004)\end{array}$ & $\begin{array}{r}\text { Period } \\
(2005-2\end{array}$ \\
\hline & $\begin{array}{c}\text { coef } \\
\text { (p-value) }\end{array}$ & $\begin{array}{c}\text { coef } \\
(p-\text { value })\end{array}$ & $\begin{array}{c}\text { coef } \\
(p-\text { value })\end{array}$ & $\begin{array}{c}\text { coef } \\
\text { (p-value) }\end{array}$ & $\begin{array}{c}\text { coef } \\
(p \text {-value })\end{array}$ & $\begin{array}{r}\text { coe }) \\
(p-v a l\end{array}$ \\
\hline \multirow[t]{2}{*}{$\alpha$} & -0.0073 & 1.7479 & -4.8332 & 1.4979 & 1.9705 & 0.23 \\
\hline & $(0.9964)$ & $(0.2614)$ & $(0.2030)$ & $(0.1183)$ & $(0.4643)$ & $(0.694$ \\
\hline \multirow[t]{2}{*}{ ShariahComp } & 0.4689 & 0.5282 & 0.2585 & 0.2225 & 0.4467 & 0.037 \\
\hline & $(0.2342)$ & $(0.1722)$ & $(0.7307)$ & $(0.1935)$ & $(0.2691)$ & $(0.731$ \\
\hline \multirow[t]{2}{*}{ LMktCap } & 0.2001 & -0.2032 & 1.3736 & $-0.3059^{*}$ & -0.3970 & -0.04 \\
\hline & $(0.5507)$ & $(0.5063)$ & $(0.1061)$ & $(0.0817)$ & $(0.4048)$ & $(0.669$ \\
\hline \multirow[t]{2}{*}{ DebtAsset } & -0.2747 & 0.0576 & -2.9873 & 0.1306 & 0.0996 & 0.181 \\
\hline & $(0.6503)$ & $(0.9035)$ & $(0.2113)$ & $(0.3737)$ & (0.6716) & $(0.524$ \\
\hline \multirow[t]{2}{*}{ BTM } & -0.1725 & -0.0853 & -0.3734 & 0.0551 & 0.0138 & -0.02 \\
\hline & $(0.2361)$ & $(0.4964)$ & (0.3023) & $(0.5092)$ & $(0.9317)$ & $(0.789$ \\
\hline \multirow[t]{2}{*}{ FCFlow } & 1.3351 & 0.6354 & 1.2228 & $1.3058^{*}$ & 3.9758 & 1.061 \\
\hline & $(0.4160)$ & $(0.6795)$ & $(0.7585)$ & $(0.0840)$ & $(0.2342)$ & $(0.031$ \\
\hline \multirow[t]{2}{*}{$R O A$} & 2.2164 & 2.5705 & 1.7023 & 1.1646 & 0.9195 & -1.65 \\
\hline & $(0.1580)$ & (0.3189) & $(0.4460)$ & $(0.2511)$ & $(0.6363)$ & $(0.310)$ \\
\hline$N$ & 600 & 332 & 268 & 60 & 26 & 34 \\
\hline$R^{2}$ & 0.0120 & 0.0130 & 0.0270 & 0.1470 & 0.2590 & 0.263 \\
\hline
\end{tabular}

The paradox is that the reverse trend, though noticeable, could not significantly be proven in the Paired $t$-test (see Table 1) on Sample B, where Islamic institutional investors supposedly fled the firms upon knowing the firms are losing the shariahcompliant status.

This, however, gives rise to suspicion that Islamic institutional investors' flights from the firms which later stripped of shariah-compliant status (Sample B) were made in advance prior to the change in shariah-compliant status which explains the low Islamic investors' presence even during shariah-compliant period prior to the annulment of its shariah-compliant status. This perhaps could be due to influence by firm's other characteristics as shown by the results of the OLS regression analysis (see Table 2) such as LMktCap (proxy for wealth) with coefficient of -0.3059 at $10 \%$ level, meaning, negatively correlated to Islamic institutional investors and FCFlow (proxy for cash) with coefficient at 1.3058 for overall period at $10 \%$ level, or positively correlated to Islamic institutional investors respectively.

Table 3: Sample Statistic: Average Islamic Institutional Investors' equity Ownership for Sample A and Sample B (in percentage)

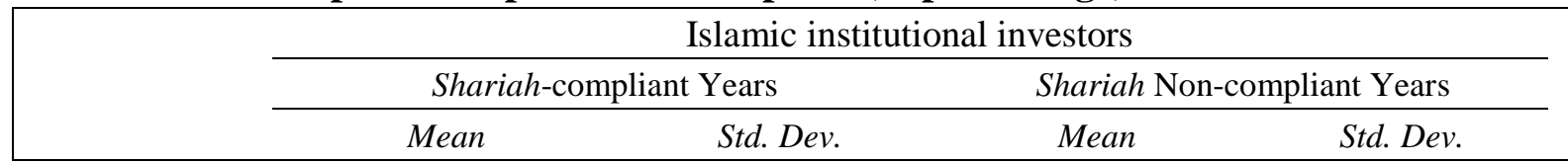




\begin{tabular}{|ccccc|}
\hline $\begin{array}{c}\text { Sample A } \\
\text { Overall Period }\end{array}$ & 1.47 & 4.77 & 1.06 & 4.55 \\
$\begin{array}{c}\text { Period-P1 } \\
(2000-2004)\end{array}$ & 1.32 & 3.51 & 0.89 & 3.30 \\
$\begin{array}{c}\text { Period-P2 } \\
(2005-2009)\end{array}$ & 1.66 & 5.97 & 1.26 & 5.74 \\
\hline Sample B & & & & \\
Overall Period & 0.23 & 0.92 & 0.06 & 0.20 \\
$\begin{array}{c}\text { Period-P1 } \\
\text { (2000-2004) }\end{array}$ & 0.42 & 1.33 & 0.08 & 0.19 \\
$\begin{array}{c}\text { Period-P2 } \\
(2005-2009)\end{array}$ & 0.09 & 0.39 & 0.05 & 0.22 \\
\hline
\end{tabular}

Note: The samples comprised of 330 firms divided into Sample A (300 firms) and Sample B (30 firms). Sample A comprises firms attaining shariah-compliant status and included in the Islamic Index and on the contrary Sample B consists of firms losing shariah-compliant status and excluded from the Islamic Index. Shariah-compliant years refer to financial years in which the firms are in the Islamic Index while shariah non-compliant years refer to financial years in which the firms are not in Islamic Index. Period-P1 and Period-P2 represent market recovery and market stability period respectively. DivSize is the dividend size calculated as dividend amount divided by ordinary shares. Islamic institutional investors refer to the Islamic institutional investors' equity ownership in the firms which is presented in percentage of ownership.

Ironically, high LMktCap for Sample B (see Table 4), would sometimes, irrespective of the market conditions, indicate overvaluation of firms' wealth as the firms in Sample B comprises mature firms with a varying degree of gestation years and probably at the tail-end of their life cycles. While on the other hand, lower FCFlow, especially during market stability period (Period P2) when dividends are most expected, scares away Islamic institutional investors as the firms' capacities to pay dividend diminish.

Table 4: Descriptive Statistics: Means for Firms' wealth Characteristics for Sample A and Sample B

\begin{tabular}{|c|c|c|c|c|c|c|}
\hline & \multicolumn{2}{|c|}{ Sample A } & \multicolumn{4}{|c|}{ Sample B } \\
\hline & $\begin{array}{c}\text { Shariah- } \\
\text { Compliant Years }\end{array}$ & $\begin{array}{c}\text { Shariah Non-Compliant } \\
\text { Years }\end{array}$ & $\begin{array}{r}\text { Sha } \\
\text { Compli } \\
\end{array}$ & $\begin{array}{l}h \text { - } \\
\text { Years }\end{array}$ & $\begin{array}{r}\text { Sharia } \\
\text { Complia }\end{array}$ & \\
\hline Variables & \begin{tabular}{ll}
\multirow{2}{*}{ Mean } & Std. \\
& Dev. \\
\end{tabular} & Std. Dev. & Mean & Std. Dev. & Mean & $\begin{array}{l}\text { Std. } \\
\text { Dev }\end{array}$ \\
\hline
\end{tabular}




\begin{tabular}{|c|c|c|c|c|c|c|c|c|}
\hline \multicolumn{9}{|c|}{ (Overall Period) } \\
\hline BTM & 0.9793 & 0.7841 & 1.0589 & 1.7168 & 1.4832 & 1.4070 & 1.5471 & 0.8643 \\
\hline$R O A$ & 0.0291 & 0.1537 & 0.0801 & 0.0891 & -0.0146 & 0.1469 & -0.0122 & 0.1390 \\
\hline LMktCap & 5.1601 & 0.5500 & 4.9692 & 0.6717 & 5.5798 & 0.5782 & 5.5780 & 0.6441 \\
\hline DebtAsset & 0.1988 & 0.2241 & 0.2089 & 0.3951 & 0.3703 & 0.5292 & 0.5296 & 1.2136 \\
\hline FCFlow & 0.0958 & 0.1269 & 0.0958 & 0.1278 & 0.0815 & 0.1364 & 0.1005 & 0.1380 \\
\hline No. of Firms & \multicolumn{4}{|c|}{299} & \multicolumn{4}{|c|}{30} \\
\hline \multicolumn{9}{|c|}{ (Period-P1: 2000-2004) } \\
\hline BTM & 1.0612 & 0.8300 & 1.2286 & 2.0110 & 1.6957 & 2.0402 & 1.1957 & 1.0125 \\
\hline$R O A$ & 0.0437 & 0.0926 & 0.0737 & 0.0665 & -0.0664 & 0.2116 & -0.0610 & 0.2008 \\
\hline LMktCap & 5.2578 & 0.5255 & 5.0729 & 0.7017 & 5.4448 & 0.6084 & 5.4305 & 0.7078 \\
\hline DebtAsset & 0.2292 & 0.2541 & 0.2488 & 0.5067 & 0.5057 & 0.7408 & 0.9728 & 1.7684 \\
\hline FCFlow & 0.1069 & 0.1403 & 0.1154 & 0.1329 & 0.0370 & 0.1085 & 0.0516 & 0.0721 \\
\hline No. of Firms & \multicolumn{4}{|c|}{165} & \multicolumn{4}{|c|}{13} \\
\hline \multicolumn{9}{|c|}{ (Period-P2: 2005-2009) } \\
\hline$B T M$ & 0.8786 & 0.7138 & 0.8500 & 1.2401 & 1.3206 & 0.6338 & 1.8158 & 0.6389 \\
\hline$R O A$ & 0.0110 & 0.2043 & 0.0879 & 0.1106 & 0.0251 & 0.0408 & 0.0251 & 0.0373 \\
\hline LMktCap & 5.0398 & 0.5576 & 4.8415 & 0.6115 & 5.6831 & 0.5496 & 5.6907 & 0.5873 \\
\hline DebtAsset & 0.1613 & 0.1743 & 0.1597 & 0.1697 & 0.2669 & 0.2639 & 0.1907 & 0.2058 \\
\hline FCFlow & 0.0820 & 0.1072 & 0.0717 & 0.1173 & 0.1155 & 0.1485 & 0.1380 & 0.1648 \\
\hline No. of Firms & \multicolumn{4}{|c|}{134} & \multicolumn{4}{|c|}{17} \\
\hline \multicolumn{9}{|c|}{$\begin{array}{l}\text { Note: Sample A represents Firms attaining shariah-compliant status whereas Sample B represents } \\
\text { firms losing shariah-compliant status. Shariah-compliant years refer to financial years in which } \\
\text { the firms are in the Islamic Index while shariah non-compliant years refer to financial years in } \\
\text { which the firms are not in Islamic Index. }\end{array}$} \\
\hline
\end{tabular}

Another way to explain the results of OLS on Sample B is that the market capitalization (LMktCap) and free cash flow (FCFlow) are the real 'push factors' instead of the commonly believed ominous exclusion from the Kuala Lumpur Shariah Index (KLSI). Now, if the reason for the exodus of Islamic institutional investors from firms nearing exclusion from Kuala Lumpur Shariah Index (KLSI) (i.e. sample B) is not entirely based on the grounds of the imminent annulment of the shariah-compliant status but rather because of the 'pull or push factor' of LMktCap and FCFlow then some explanations need to be made. The significant relation of LMktCap recorded only during overall period only, whereas FCFlow is significant during overall period and also during market stability period (period-P2). Here, the speculation is that the Islamic institutional investors' probably have decided to flee prior to the shariah-compliant's annulment because they were concerned on the possible drop in market capitalization (LMktCap), which are overvalued, irrespective of the market conditions. Lower FCFlow, especially during market stability period (period-P2) when firms seize investment opportunities, have driven away Islamic institutional investors as lower FCFlow could affect the size of dividends and not attractive to Islamic institutional investors.

The drawback of the OLS regression model in this hypothesis is the minor $R^{2}$ readings which are below $18 \%$. Nonetheless, higher $R^{2}$ readings are registered in Sample 
$\mathrm{B}$ with the highest recorded at $26.3 \%$ during market stability period (Period-P2). This, however, does not negate the usefulness of the results as the model is complementary and meaningful when synthesized with the Paired $t$-test outcomes.

\section{Conclusion}

The study supports the hypothesis and confirmed Islamic investors are valuesdriven and are drawn to shariah-compliant firms. However, to suggest that they would naïvely buy and hold shares in shariah-compliant firms irrespective of the performance of the shares is implausible. While shariah compliance is their first investment criteria, other factors concerning firms' characteristics are also considered as shown by their behavior in fleeing the firms long before the firms were losing shariah-compliant status.

\section{Recommendations/ implications}

Knowing the behavior of Islamic investors are very relevant to fund managers in particular, the shariah-compliant fund managers. The results of this study also useful for policy makers involving in the structuring of security market as well as other researchers.

\section{Limitations of the Study}

This study focuses only on firms in the Islamic index in Bursa Malaysia. This is, first and foremost, due to the availability of data especially the Islamic investors' data. Further, the selection of Islamic institutional investors to represent the overall Islamic investors is based on the practicability of obtaining reliable data. Indeed there are also Islamic retail investors as well. The fact is that, while Islamic institutional investors are certified by their respective shariah boards under the watchful eye of the Security Commission of Malaysia no information could be obtained to identify retail investors. Even if such information were made available the difficulty would be to identify whether they subscribe to the shariah principles in their investment ventures as the shariah compliance is a matter of personal choice and an expression of devoutness which is not enforceable. The results of this study may not be representative of situations in other Islamic indices or screens.

\section{Suggestions for Future Research}

This study's conclusions and limitations open up a multitude of opportunities for further research. Similar study should be extended to other Islamic indices or screens in order to analyze the behavior of Islamic investors in other regions.

\section{References}

Al-Qaradawi, Y. (1999). Fiqh az-Zakah- A comparative study. London: Dar al-Taqwa Ltd.

Baker, G. \& Hall, B. (2004). CEO incentives and firm size. Journal of Labor Economics, 22: 767-798.

Barber, B. \& Lyon, R. (1997). Detecting long run abnormal stock returns: The empirical power and specification of test statistics. Journal of Financial Economics, 43: 341-372. 
Bichara, Z. (2008). Institutional ownership and dividend policy: A framework based on tax clientele, information signaling and agency costs. Theses and Dissertation paper. UNT Libraries. Retrieved from http:// digital.library.unt. edu/ ark: / 67531/ metadc9004/

Campbell, J.Y. \& Vuolteenaho, T. (2004). Bad beta, good beta. American Economic Review, 94(5): 1249-1275.

Del Guercio, D. (1996). The distorting effect of the Prudent-Man Laws on institutional equity investments. Journal of Financial Economics, 40: 31-62.

Enderle, G. (2000). Whose ethos for public goods in a global economy? An exploration in international business ethics. Business Ethics Quarterly, 10(1): 131-144.

Fama, E.F. \& French, K.R. (2007). The Anatomy of Value and. Growth Stock Returns, CRSP Working Paper. Retrieved from SSRN: https://ssrn.com/abstract=806664 or http://dx.doi.org/10.2139/ssrn.806664

Fenn, G. \& Liang, N. (2001). Corporate payout policy and managerial stock incentives. Journal of Financial Economics, 60: 45-72.

Forte, G. \& Miglietta, F. (2007). Islamic Mutual Funds as Faith-Based Funds in a Socially Responsible Context. Conference Paper. Retrieved from: papers.ssrn.com/sol3/papers.cfm?abstract_id=1012813

Fung, H.G., Law, S.A., \& Yau, J. (2010). Socially Responsible Investment in a Global Environment, 25-43 (Cheltenham, UK, and Northampton, MA: Edward Elgar Publishing Limited).

Geczy, C.C., Stambaugh, R.F. \& Levin, D. (2005). Investing on socially responsible Mutual funds. Working Paper, The Rodney L. White Center of Financial Research, The Wharton School, University of Pennsylvania. Retrieved from: http://papers.ssrn.com/sol3/papers.cfm?abstract_id=416380

Girard, E. \& Hassan, K. (2006). Faith-Based Ethical Investing: The Case of Dow Jones Islamic Indexes. Retrieved from papers.ssrn.com/sol3/papers.cfm? abstract_id= 1808853.

Gompers, P. \& Metrick, A. (2001). Institutional investors and equity prices. Quarterly Journal of Economics, 116: 229-259.

Grullon, G. \& Michaely, R. (2004). The information content of share repurchase programs. Journal of Finance, 59: 651-680.

Hakim, S. \& Rashidian, M. (2002). Risk \& Return of Islamic Stock Market Indexes, conference paper: Economic Research Forum Annual Meeting Sharjah UAE October 26th. Retrieved from: http://www.lariba.com/knowledgecenter/articles/index.htm

Heinkel, R., Kraus, A., \& Zechner, J. (2001). The effect of green investment on corporate behavior. Journal of Financial and Quantitative Analysis, Dec 2001; 36(4); ABI/INFORM Global. pg. 431.

Hong, H. \& Kacperczyk, M. (2009). The price of sin: The effects of social norms on markets, Journal of Financial Economics, 93(1): 15-36.

Hussein, K. (2005). Islamic investment: Evidence from Dow Jones and FTSE Indices. Working paper, Islamic Business Research Centre, Norway

Jensen, M. (1986). Agency costs of free cash flow, corporate finance, and takeovers. American Economic Review, 76: 323-329.

Lee, D.D. \& Faff, R.W. (2009). Corporate sustainability performance and idiosyncratic risk: A global perspective. The Financial Review, 44(no): 213-237.

Lougee, B. \& Wallace, J. (2008). The corporate social responsibility (CSR) trend. Journal of Applied Corporate Finance, 20(1): 96-108. 
Mansor, F. (2006). Wealth Creation and Wealth Generation: Analysis From Qur`anic Perspective, conference paper: National Seminar In Islamic Banking \& Finance, August 29-30, 2006, Kuala Lumpur, Malaysia. (Unpublished). Retrieved from: http://eprints.um.edu.my/927/

Mirza, M. (2013). Investing For Hajj- Early Bird Hajj Financial Planning, Amanafunds. Retrieved from http: //www.amanafunds.com/ retail/hajj/ hajj1.shtml

Naughton, S. \& Naughton, T. (2000). Religion, ethics and stock trading: The case of an Islamic equities market. Journal of Business Ethics, 23: 145-159.

Rahim, F., Ahmad, N. \& Ahmad, I. (2009). Information transmission between Islamic stock indices in South East Asia. International Journal of Islamic and Middle Eastern Finance and Management, 2: 7-19.

Rahim, R.A. \& Yong, O. (2010). Initial returns of Malaysian IPOs and Shariahcompliant status. Journal of Islamic Accounting and Business Research, 1(1): 60-74.

Rahman, F. A. \& Wajdi, F. M., 2006. Dividend signaling hypothesis and agency cost: An investigation on Shariah and Non Shariah-Compliant firms in Kuala Lumpur. Shariah Index, Empirika, 19(1): 1-9.

Rosly, S. (2005). Critical issues on Islamic banking and financial market. Bloomingdale, Indiana: Authorhouse

Sadeghi, M. (2008). Financial performance of Shariah-Compliant Investment: Evidence from Malaysian stock market. International Research Journal of Finance and Economics, 20: 15-26.

Shafi, M. (1968). Distribution of Wealth in Islam. Conference Paper Read at the International Islâmic Conference, Rawalpindi, Pakistan on February 13, 1968 Muhammad Hasan Askari/Karrar Husain, Tran.

Smith, A. (1776). An inquiry into the nature and causes of the wealth of nations, Edited by R. H. Campbell, A. S. Skinner, W. B. Todd. Oxford: Clarendon Press, 1976.

Smith, C. \& Watts, R. (1992). The investment opportunity set and corporate financing, dividend, and compensation policies. Journal of Financial Economics, 32: 263-292.

Statman, M., Fisher, K.L. \& Anginer, D. (2008). Affect in a behavioral asset pricing model, Financial Analysts Journal, 64 (2): 20-29.

The Qur'an, Trans. by Muhammad Muhsin Khan \& Muhammad Taqi-ud-Din Al-Hilali (English and Arabic Edition), Dar-us-Salam Publication online version retrieved from http://www.noblequran.com/translation/ on 12 Jan 2017

Wald, J. (1999). How firm characteristics affect capital structure: An international comparison. Journal of Financial research XXII, 161-187.

\section{GLOSSARY AND TRANSLITERATION}

Gharar- Excessive risk and uncertainty in business and finance

Hadith- A report from one or more Companions (early Muslims who are close associate to the Prophet) of what Prophet Muhammad (pbuh) said or did

Hajj - pilgrimage to Mecca which is the $5^{\text {th }}$ pillar of Islam 
Halal- Things/acts lawful in Islamic law

Haram- Things/acts unlawful in Islamic law

Ijtihad-Derivation and formulation of a shariah opinion by a qualified scholar for matters not clearly stated in the Quran and Hadith through reasoning

Maisir [or Qimar]- gambling or speculation

Pbuh - is the abbreviation of "Peace be upon him" which is a phrase that practicing Muslims often say after saying (or hearing) the name of the prophet of Islam

Riba- any pre-agreed excess paid or received over and above the principal in a loan contract; commonly equated with interest or usury in modern times

Shariah [or Sharia]- The method of conduct that Muslims must employ in their lives, revealed in the Quran and Sunnah

Sunnah - The sayings and actions of Prophet (pbuh); the example of the prophet.

Zakah [or zakat] - is an obligatory form of "charity" or alms expected from every Muslim individual. Zakah literally means purification and increment of one's we 